\title{
UTILIZING MEME AS DIGITAL MARKETING STRATEGY
}

\author{
Adiella Yankie LUBIS*, Prasetya Yoga SANTOSO and Bagus FITRIANTO \\ Universitas Prof. Dr. Moestopo (Beragama) \\ *yankie.lubis@dsn.moestopo.ac.id
}

\begin{abstract}
How to utilize memes in digital marketing communication strategy (@shopdear) to increase engagement? This question arises because, so far, memes are better known as visual content (consisting of images and writing) and often contain elements of social, political, religious messages, and others. If it departs from the initial observations where the researcher assumes that memes can develop into a communication character through the tone of voice of a brand, the results of this study will also be aimed at answering and describing the relationship between the two. In this study, we implement the post-positivism paradigm. Looking at the objectives and research paradigm, from several variants of the research approach, we use a qualitative approach. The authors uses the case study method to obtain comprehensive results in detail from several sources/subjects involved. If in general, meme marketing is used to produce viral marketing, DEAR uses memes more as a medium of expression and a form of creativity. However, in fact the researcher saw that the concept of this meme became a link between DEAR and an audience who had the same frequency, one taste in acting, thinking, and behaving. Finally, the use of this meme is considered quite successful in the DEAR digital marketing communication strategy on Instagram, especially in the market segmentation of today's Generation Z.
\end{abstract}

Keywords: Digital Marketing, Marketing Strategy, Meme.

\section{BACKGROUND}

The development of digital marketing is not only related to the social conditions of the community or the digital platform, but also the method or marketing strategy itself. According to Seth Godin, today's marketing is no longer about goods or products, but about stories being told. Among the many competitors, differentiation has to be done by taking other avenues, and the route is content. When a brand tells a unique story, consumers begin to trust and like it. That emotional response is the key to the modern world of marketing (Godin, 2019, pp. 26-32). In line with the opinion of Damian Ryan and Calvin Jones in a book on digital marketing. As previously explained by Godin, in the book they also argue that understanding the audience is the real key to unlocking all the potential in digital marketing, because digital marketing is actually not about technology, but about people (Ryan \& Jones, 2009, p. 12). Therefore, dealing with other people (consumers) to build relationships or engagement, as well as increasing sales potential.

Since a few years ago, when the internet began to become a space for intensive mass communication, meme content has become popular among social media users. At certain times, memes in Indonesia actually appear more often to convey a social critique, and this realm generally leads to political interests. This is in accordance with what Shifman (2014) said in (Mahadian et al., 2019, p. 37) that memes have the function of conveying ideas, ideas, attitudes, and discourses, memes are commonly conveyed in the context of non-serious, informal communication. , or even humor, which is the product of globalization. This non-serious, informal, and humorous way of communicating spreads very quickly through the internet, like a virus that can spread quickly to infect many people in a fast (viral) time. Therefore, this method was quickly imitated by many people and encouraged the evolution of communication and culture in various places. Likewise with its use as a marketing strategy or advertising content, because this meme-shaped content is considered to have the potential to spread quickly and give its own impression to the audience (Listiyorini, 2017, p. 66).

In this modern digital-based business era, competition in digital marketing strategies has recently opened a new paradigm for entrepreneurs in Indonesia to continue to seek insights about digital marketing strategies which include techniques for building a brand, marketing techniques, and advertising techniques. Plus since the emergence of the Covid-19 pandemic, where all community activities have shifted to digital systems, ranging from communication systems, promotions, to transactions, as the mass media said that, "...the use of social media such as Whatsapp, Facebook, and Instagram has surged above 40\% during the coronavirus pandemic." (Burhan, 2020). Therefore, it is natural that this limited space for movement has succeeded in creating new consumer patterns in the sales and buying ecosystem of a business whose entire activities are in the digital market space.

This research will focus on digital marketing activities on Instagram carried out by @shopdear, an MSME engaged in the fashion sector. Through analysis from case studies, researchers will see how the communication strategy in digital marketing is carried out by MSMEs, especially on content that uses memes. As a new information later for the community, the researcher will also describe how the meme concept has developed into a way of communication on the brand through the tone of voice character of the brand. In particular, this research will examine how to use memes in digital marketing communication strategies (@shopdear) to increase engagement? This question arises because, so far, memes are better known as visual content (consisting of images and writing) and often contain elements of social, political, religious messages, and others. If it departs from the initial observations where the researcher assumes 
that memes can develop into a communication character through the tone of voice of a brand, the results of this study will also be aimed at answering and describing the relationship between the two.

\section{METHOD}

Researchers will use the post-positivism paradigm. In contrast to the positivism perspective, the post-positivism perspective refers that not everything can be understood as a whole (Krauss, 2015, p. 760). According to Tahir, the post-positivism paradigm is unable to obtain facts from a reality if the researcher distances himself from the existing reality. The researcher's relationship with reality must be interactive (Tahir, 2011, pp. 57-58). Therefore, it is necessary to use the principle of triangulation, namely the use of various methods, data sources, and data. Looking at the objectives and research paradigm, from several variants of the research approach, the researcher will use a qualitative approach. The focus of qualitative research is on the process and the meaning of the results. Qualitative research attention is more focused on human elements, objects, institutions, and the relationship or interaction between these elements. According to Hammersley (2007) in Katsutoshi Fushimi (Fushimi, 2021, p. 3), it is explained that qualitative research studies have the same roots. They both explore the deep meaning of social phenomena and are subjective, inductive, and interpretive regardless of differences in approach (eg, narrative research, phenomenology, grounded theory, ethnography, and case studies). Based on some of the opinions above regarding the research approach used in qualitative research, in this study, the researcher will use a qualitative approach that leads to a case study.

The method that the researcher will use in this research is a case study. According to Creswell (1998) in Herdiansyah (Herdiansyah, 2010,p. 76), states that a case study is a model that emphasizes the exploration of a system that is limited to a case or several cases in detail, accompanied by in-depth data mining involving various sources of information that are rich in context. The author uses the case study method to obtain comprehensive results in detail from several sources/ subjects involved in this research in order to obtain results that can answer a case.

According to Creswell in Wahyuningsih(Wahyuningsih, 2013, pp. 2-3) there are several characteristics of a case study, namely: (1) identifying the "case" for a study; (2) the case is a "system bound" by time and place; (3) case studies use various sources of information in data collection to provide a detailed and in-depth description of the response to an event; and (4) by using a case study approach, the researcher will "spend time" in describing the context or setting for a case. This implies that a case can be studied as an object of study, or considered as a methodology.

Data collection techniques that will be carried out in this study include conducting interviews, independent observations, and non-participant observations. While looking at the current conditions which are still in a pandemic condition, then some options for conducting interviews are to conduct meeting calls via Zoom or Google Meet. Several other ways will also be taken in conducting surveys by distributing questionnaires to see how the public responds or opinions on the object brand's digital marketing communication strategy. In addition, researchers will conduct searches via digital media (internet) for literature data that will be used during the research.

\section{RESULTS AND DISCUSSION}

Departing from the communication style and brand positions, the next researcher will discuss the brand tone of voice. In the process of developing the equity of a brand or branding, a certain style of communication or language is created as a way of conveying the personality of a brand to the audience. Then to be able to do this, first the techniques from linguistics can be applied to describe, and then formulated into the brand tone of voice (Delin, 2005 , p. 2). At the formulation stage, it is important to remember that insight into target consumers also needs to be considered, because the brand tone of voice must be ensured that consumers can access and like it (Delin, 2005 , p. 11), which means it is also related to Gen Z. The characteristics of Gen $\mathrm{Z}$ in communicating, according to sources previously mentioned one of which is an informal and to the point way of communicating (Wolf \& McQuitty, 2011, p. 154). Then another source also added that there are rules for being able to communicate and interact with generation Z (Töröcsik et al., 2014, p. 31), including the following:

1. Sharing is their hallmark; namely the information obtained has no value, so they want, expect and convey everything for free;

2. They are pragmatic; they reject things that are too expensive, too popular or too uniform (except for their 'cool' brand, they would give anything for this);

3. Pengalaman dan kesenangan sangat penting bagi mereka;

4. Due to excessive media supply, they are very selective, they criticize, click, and surf the internet;

5. Mereka menyukai presentasi yang provokatif, ekstrem, spektakuler, dan seperti pertunjukan.

An image can convey a message through signs that are now far more important than the product itself. But of course these messages will be understood more quickly by an audience who has one frequency in understanding or liking an object(Nandy, 2021,p. 79). The entire explanation above is very representative of DEAR's behavior on his Instagram account. As previously mentioned, DEAR quite often uses memes to convey a message, whether related to product promotion or just to share content that has an impact on audience engagement. The image below is a 
detailed representation of the content, which contains a variety of mixed messages such as a product display, a narrative of a story context or inspiration related to the product, and the appearance of objects based on reality (Holland, 2020, p. 5). This content is uploaded in the form of a carousel post (consisting of several images), and is another example of Figure 1 as a display of meme content for the promotion of DEAR Volume 2 products.

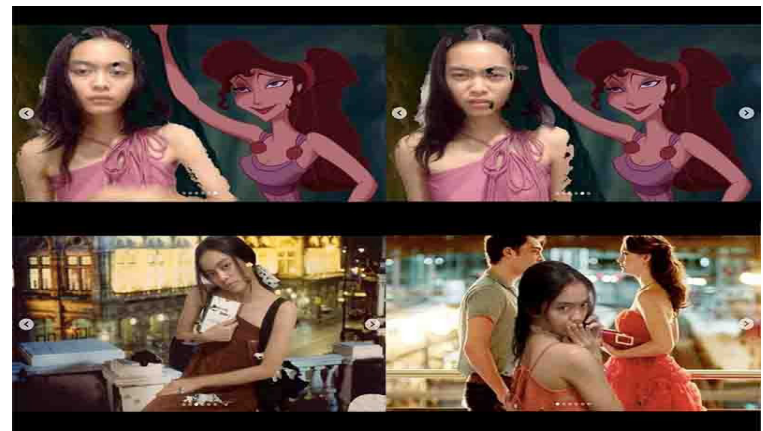

Figure 1. Examples of images in promotional meme content Vol. 2 (2)

https://www.instagram.com/p/CFRwjncHe-n/

The content uploaded by DEAR above shows Dhira as a subject who uses several types of Volume 2 products with several objects from various scenes in the film, including Gossip Girl, Before Sunrise, and Hercules. The images are packaged into photos that show Dhira is also involved in all these scenes. Then the product used is also chosen based on the match between the color of the dress and the background image used (mix \& match concept). As a single piece of content, the pictures above are an implementation of the use of memes for product promotion content, for example for the Volume 2 product above. The purpose of promoting and introducing DEAR's newest products is also shown by writing captions on the content for Figure 1, in the form of the following captions:

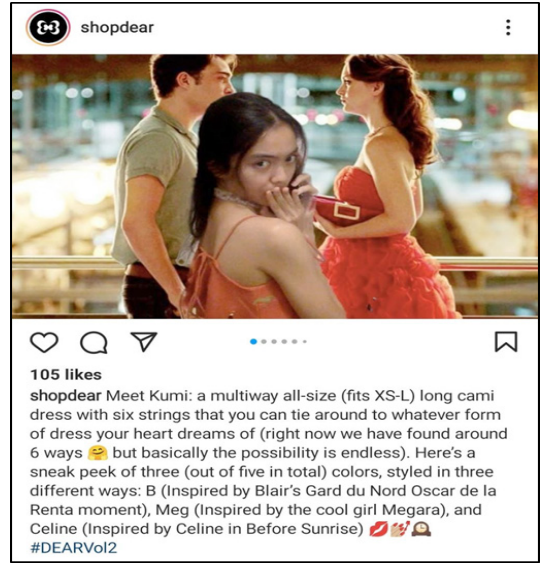

Figure 2. Example of caption in promotional meme content Vol. 2 (3)

https://www.instagram.com/p/CFRwjncHe-n/

In the caption of the content, it contains product specifications used, namely Kumi, a type of long cami dress product with 6 straps that can be used in various styles, and it is also explained that this product can be used by consumers with other styles, not only as exemplified by DEAR. If you return to the persuasive strategy (Bolatito, 2012, p. 10), this content has also fulfilled its three elements, which are the use of background images from scenes from popular films and quite relevant to the audience (pathos), then the concept of mix and match which is shown through specifications. product (logos), and product designation used by Dhira to display her style of dress and credibility as a brand with character (ethos).

To see how this content correlates with memes, we will look at the elements in a meme according to Milner (Milner, 2016, pp. 23-39) in his book The World Made Meme, as follows:

\section{Multimodality}

As stated by (Nandy, 2021, pp. 78-79) that in an Instagram post content is multimodal text with image elements, captions, comments, and emoticons.

\section{Reappropriation}

Reappropriation is described as a Use \& Reuse concept in meme circulation, where there is a macro image that can facilitate expression by re-adjusting a predetermined visual subject, such as using a scene image from a film (macro image) and Dhira (visual subject expression).

\section{Resonance}

Meme is a form of inside jokes in internet culture, where through meme content it can build engagement between creators and audiences. That way the topic raised in a meme can successfully resonate if the topic is relevant to the audience, like the films in Figure 1.

\section{Collectivism}

Engagement is at the core of collectivism in social media, in resonance with the audience, meme content becomes an enlivening collective product. From this aspect, the output can be measured in a form that is understood together (DEAR and the audience) as shown in Figure 1.

\section{Spreads}

As a form of addition to the existence of collectivism, memes that are inside jokes will never stop being reproduced as a form of group communication. With the content uploaded by DEAR as in the example in Figure 1, it will create engagement with the same behavior towards meme content in its community (audience). As shown below, is an example of content that was tagged by one of the DEAR audience accounts to the @ shopdear account.

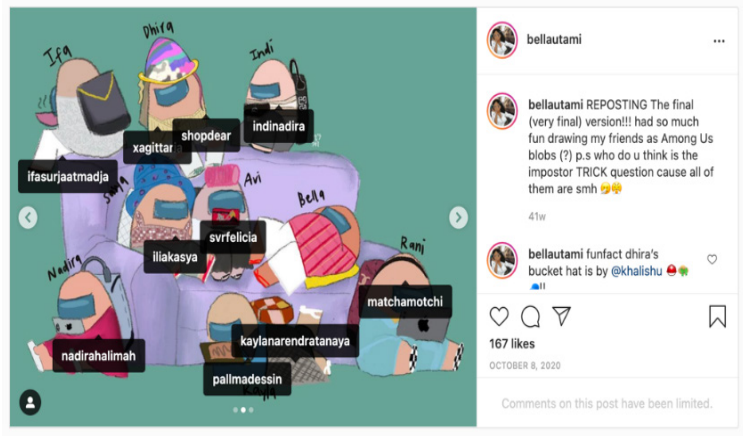

Figure 3. Examples of meme content from audience and DEAR https://www.instagram.com/p/CGEYkqiH2Ku/ 
Based on the explanation and analysis of Figure 1 posted by DEAR, it shows that the content already includes all elements in the meme and has also had an impact on the audience. Of course, this has something to do with Social Media Engagement (SME), so that the use of memes in marketing communication strategies can be interpreted as a system (Cannizzaro, 2016, pp. 562-586). And the system contained in this case, becomes an implementation of advertising activities for clothing products that are promoted through various meme content. The role of memes as an element in advertising is also explained in a thesis entitled Just A Joke (Holland, 2020, p. 45), and the following explanation:

"Internet memes often take inspiration from the entertainment industry, with sources such as television, cartoons and comic books providing highly exaggerated visuals. Another key influence - perhaps surprisingly - is the advertising industry. Much like popular entertainment, advertisers frequently use overemphasised visuals to connect with their audiences."

In addition, the use of memes in marketing has also been written in an article in the Journal of Management Studies in 2014 entitled Using "Memes" in Word of Mouth (WOM) to Increase Brand Awareness. This paper is also a reference for previous research for this research, and some of the core points of this paper are the use of memes for viral marketing (a form of the spread concept in the meme above). Then, three elements are also written that can support the success of a meme in creating engagement, such as: 1) knowing the target market; 2) understand memes; and 3) fun (Renata, 2014, p. 186). If this is related to the example of meme content uploaded by DEAR (Figure 1), all those elements are already included. First, DEAR must have known their target market and reflected themselves as part of that target market (ie Gen Z). Second, for understanding memes, Dhira has also explained, “... we and memes ourselves, it seems like we were from the 9gags era, until we entered Tumblr, to Twitter, so it seems like we consume memes every day. You could say it's like our second nature", so we can be sure that Dhira and Sasya have understood memes. Third, the fun aspect can be seen from the way each content is uploaded and also the caption written on the content. Besides that, fun or having fun has become part of the DEAR character itself.

The use of memes carried out by DEAR has formed a culture in its digital marketing communication strategy, and Instagram has become a space where the culture that occurs is produced, distributed, and consumed (Murfianti, 2019 , p. 44). This strategy also does not always guarantee a virality or high engagement results, but at least that way a brand can build a connection and an interaction occurs in it. The interactions that occur between brands and their audiences or consumers through social media are currently consumer engagement in the form of likes and comments. According to Beig and Khann (Beig \& Khan, 2018, pp.
2-3), in SMM (Social Media Marketing), brand experience can be achieved through interaction and content sharing, then both can be measured based on the elements included in the brand experience. , including sensory, affective, behavioral, and intellectual responses with the following explanations: 1) sensory experience attracts all five senses (sight, touch, sound, smell, and taste) through which the product is experienced by the customer; 2) affective experiences appeal to consumers' sentiments, emotions, and most of the deepest feelings; 3) intellectual experiences stimulate consumers' thinking processes with the intention of creating cognitive experiences and problem solving that engage consumers creatively; and 4) behavioral experience occurs when a brand evokes various types of behavior such as physical actions. Then the correlation to SME (Social Media Engagements) is currently quoted in the article (Beig \& Khan, 2018, p. 5) as follows:

"This interaction between brands and consumers on the SM becomes consumer engagement (Hollebeek, Glynn, \& Brodie, 2014). Consumer engagement leads to response on behavioural and cognitive levels in the form of likes' and 'comments' (Simon et al., 2013), since brand experiences are evoked by different stimuli when a customer interacts with a brand (Brakus et al., 2009). Thus interaction through SM positively affects brand experience."

So with an explanation related to SME, the meme content aspect in the DEAR digital marketing communication strategy on Instagram has succeeded in generating engagement with the audience. As a communication strategy, memes can have a positive impact as well as help the appearance of a brand's character in digital marketing. In the midst of increasingly fierce competition, a brand is required to be unique as a differentiator, and the use of this meme is one of DEAR's strategies to outperform its competitors. Through the emotional involvement and personal characteristics that Dhira and Sasya do in marketing communications, they also support clear, authentic communication, and create an interesting narrative, so as to give pleasure and enthusiasm to the audience. In addition, the communication that is established will feel more sincere and honest, and this will be very valuable in the view of the audience, especially regarding engagement (Matejic, 2015, p. 7).

Based on the results of interviews with Indah (consumer) directly, it has been described that DEAR has succeeded in building its brand image, "...I think the DEAR brand has a rather quirky character (unique), and not too many brands whose style is quirky cutie- so cutie (cute)", so that the percentage of consumer buying interest can also be maintained and has the potential to increase (Chovanová et al., 2015, p. 616). The use of memes can also be interpreted as a form of marketing communication strategy that is very suitable for the audience (especially the market niche of Gen Z) and can create positive brand associations and 
initiate buying actions because of the positive brand image that is seen (value in the minds of consumers). consumers) (Chovanová et al., 2015, p. 619). On the other hand, the establishment of this brand image also shows an implementation of the concept and identity (deadstock and Y2K) that has been successfully realized.

Then the interaction and linkages built with the general audience or \#DEARFriendsClub indicates that technically, the established SME also acts as a support system for DEAR marketing, because the essence of SME involvement is to build connections with its online community in the digital market. (Sherman \& Smith, 2013, p. 10). Thus, what DEAR needs to do in the future is to maintain a good relationship or interact with the audience (interaction) and maintain Instagram's performance with consistency in terms of the frequency of sharing content (content sharing) through various features on Instagram, so that it can provide a brand experience. towards consumers in a sustainable manner (Beig \& Khan, 2018, p. 4).

\section{CONCLUSSION}

Related to the marketing communication strategy contained in the DEAR digital marketing pattern clearly has an attachment to the use of memes. In various uploaded content, DEAR often uses memes as an instrument to build connections and relationships with the audience. In addition, memes are also an implementation of the concept and character of DEAR. If in general, meme marketing is used to produce viral marketing, DEAR uses memes more as a medium of expression and a form of creativity. However, in fact the researcher saw that the concept of this meme became a link between DEAR and an audience who had the same frequency, one taste in acting, thinking, and behaving. Finally, the use of this meme is considered quite successful in the DEAR digital marketing communication strategy on Instagram, especially in the market segmentation of today's Generation Z.

\section{REFERENCES}

Beig, F. A., \& Khan, M. F. (2018). Impact of Social Media Marketing on Brand Experience: A Study of Select Apparel Brands on Facebook. Vision: The Journal of Business Perspective, 22(3). https://doi. org/10.1177/0972262918785962

Bolatito, O. (2012). The Linkage between Persuasion Principles and Advertising. New Media and Mass Communication, 8, 7-11.

Burhan, F. A. (2020, March 27). Pengguna Whatsapp dan Instagram Melonjak 40\% Selama Pandemi Corona. Katadata. https://katadata.co.id/febrinaiskana/ digital/5e9a41f84eb85/penggunaan-whatsapp-daninstagram-melonjak-40-selama-pandemi-corona

Cannizzaro, S. (2016). Internet memes as internet signs: A semiotic view of digital culture. Sign Systems Studies, 44(4). https://doi.org/10.12697/SSS.2016.44.4.05
Chovanová, H. H., Korshunov, A. I., \& Babčanová, D. (2015). Impact of Brand on Consumer Behavior. Procedia Economics and Finance, 34. https://doi. org/10.1016/S2212-5671(15)01676-7

Delin, J. (2005). Brand Tone of Voice. Journal of Applied Linguistics, 2(1), 1-44. https://doi.org/10.1558/ japl.2005.2.1.1

Fushimi, K. (2021). Qualitative Research is not a Unified Paradigm: Implications for the Evaluation of Qualitative Research Studies. JICA Ogata Sadako Research Institute for Peace and Development, 15, 1-18.

Godin, S. (2019). This is Marketing

Herdiansyah, H. (2010). Metode Penelitian Kualitatif untuk Ilmu-ilmu Sosial (A. Suslia \& D. Mandasari, Eds.; 2nd ed.). Salemba Humanika.

Holland, C. R. (2020). Just a Joke? The Social Impact of Internet Memes. https://doi.org/10.13140/ RG.2.2.17476.04485

Krauss, S. (2015). Research Paradigms and Meaning Making: A Primer. The Qualitative Report. https:// doi.org/10.46743/2160-3715/2005.1831

Listiyorini, A. (2017). Wacana Humor dalam Meme di Media Online sebagai Potret Kehidupan Sebagian Masyarakat Indonesia. Litera: Wacana Humor Dalam Meme Di Media Asing, 16(1), 64-77.

Mahadian, A. B., Sugandi, M. S., \& Prasetio, A. (2019). Evolusi Wacana Politik dalam Internet Meme. Jurnal Studi Komunikasi Dan Media , 23(1), 37-52.

Matejic, N. (2015). Social Media Rules of Engagement: Why your online narrative is the best weapon during a crisis (1st ed.). John Wiley \& Sons Australia, Ltd.

Milner, R. M. (2016). The World Made Meme. The MIT Press.

Murfianti, F. (2019). Meme di Era Digital dan Budaya Saber. Jurnal Penelitian Seni Budaya, 11(1), 42-50.

Nandy, R. (2021). The Exotic as Luxury: Visual Narrative Advertisements of Indian Luxury Goods on Instagram. In A. Sikarskie (Ed.), Storytelling in Luxury Fashion (1st ed., pp. 71-86). Routledge.

Renata, M. (2014). Menggunakan Meme dalam Word of Mouth (WoM) untuk Meningkatkan Brand Awareness. Jurnal Studi Manajemen, 8(2), 183-192.

Ryan, Damian., \& Jones, Calvin. (2009). Understanding Digital Marketing: Marketing strategies for engaging the digital generation. Kogan Page.

Sherman, A., \& Smith, D. E. (2013). Social Media Engagement for Dummies (N. Sholly, A. Fandrei, R. Whitney, A. Graham, J. Waters, K. Kirschner, A. Sullivan, \& C. Case, Eds.; 1st ed.). 
Tahir, M. (2011). Pengantar Metodologi Penelitian Pendidikan. Universitas Muhammadiyah Makassar.

Törőcsik, M., Szücs, K., \& Kehl, D. (2014). How Generations Think: Research on Generation Z. Acta Universitatis Sapientiae, Communicatio, 1, 23-45.
Wahyuningsih, S. (2013). Metode Penelitian Studi Kasus. UTM Press.

Wolf, M., \& McQuitty, S. (2011). Understanding the do-ityourself consumer: DIY motivations and outcomes. AMS Review, 1(3-4). https://doi.org/10.1007/ s13162-011-0021-2 